\title{
State Practice of Asian Countries in International
}

\section{Law}

Korea

\author{
Buhm-SukBaek*
}

\section{Human Rights - Refugee - Treaties}

\section{Decision of Supreme Court Concerning the 'Revocation of Denial of Refugee Status,' Supreme Court Decision 2016Du56o8o}

(decided on July 11, 2017)

\section{Facts of the Case and Issues Presented}

One of the main issues, in this case, is whether same-sex orientation constitutes, within the meaning of the Article 2 subparagraph 1 of the Refugee Act, ${ }^{1}$ "a particular social group." Taking into account the provisions of the 1951 Convention Relating to the Status of Refugees (hereinafter the "Refugee Convention") and the ${ }_{1967}$ Protocol Relating to the Status of Refugees, the Court ruled that "a particular social group" under the Article 2 subparagraph 1 of the Refugee Act means a group of individuals who share an innate characteristic, an immutable shared history, or a religious faith so fundamental to their individual identities/conscience that they ought not to be required to renounce it, and who form a separate group which is perceived by the society as being distinct. Here, same-sex orientation can be deemed to constitute "a particular social group" when, as same-sex orientation is denounced in the moral norms prevailing in the refugee applicant's country of origin, its disclosure would readily expose the applicant to persecution, and the government of his/her country of origin refuses or is unable to offer protection.

* Professor, Kyung Hee University, Korea.

1 Nanminbeob [Refugee Act], Act No. 11298, Feb. 10, 2012, amended by Act No. 14408, Dec. 20, 2016, art. 2 (S. Kor.).

Article 2 (Definitions)

Definitions of the terms in this Act are as follows:

1. A "refugee" refers to an alien who is unable or unwilling to avail him/herself of the protection of his/her country of nationality owing to well-founded fear of being persecuted for reasons of race, religion, nationality, membership of a particular social group or political opinion; or who, not having a nationality, is unable or, owing to such fear, unwilling to return to the country of his/her former residence (hereinafter "the country of habitual residence") prior to entry into the Republic of Korea. 
Also, the Court highlighted that "persecution" means "acts causing a serious infringement of, or discrimination against, inherent human dignity, including threats to life, liberty, or security of person." If the risk to which the refugee applicant is likely to be exposed due to same-sex orientation exceeds the ordinary level of social reproach to reach the level of a serious infringement of, or discrimination against, inherent human dignity, including threats to life, liberty, or security of person, then such acts would constitute persecution within the meaning of the Refugee Convention. But, if the disclosed same-sex orientation would likely expose the applicant to only antipathy and social reproach from family, friends, and the general public for its contravention of moral norms in the country of origin, then it may constitute an unfair social restraint, but not persecution per se within the meaning of the Refugee Convention. Therefore, for an applicant to be recognized as a refugee, he/she must be a person whose sexual orientation has already been disclosed in the applicant's country of origin, who for that reason has been subject to specific persecution in the country of origin prior to his/her admission to the Republic of Korea, and who has a well-founded fear of being persecuted by a specific force or the government should he/she return to the country of origin. Lastly, the burden of proof of a "well-founded fear" of being persecuted rests on the applicant.

\section{Judgment}

In this case, the Court confirmed that the Plaintiff has neither disclosed his sexual orientation nor actively engaged in related activities, and also he was never subject to specific persecution on account of his homosexuality before. Thus, the Court remanded the case to the lower court (Seoul High Court) as it is difficult to conclude that the Plaintiff has a well-founded fear of being persecuted by drawing the attention of the government of his home state on account of his same-sex orientation.

\section{Comment}

Though the case was remanded, the acknowledgment by the Court that samesex orientation constitutes a particular social group within the definition of "refugee" under Article 2 subparagraph 1 of the Refugee Act, is meaningful development for the protection of human rights of LGBT individuals.

\section{Human Rights - Criminal LAW - Sovereignty}

\section{Decision of Supreme Court Decision on 'Murder Case', Supreme Court Decision ${ }_{2017}$ Do5977}

(decided on August 24, 2017) 


\section{Facts of the Case}

The Defendant had been charged with murder in the Philippines, and he was released after a Philippine court rendered a not-guilty verdict. But he was prosecuted again in a Korean trial court which sentenced him to imprisonment of ten years. The Defendant then appealed on the ground that Article 7 of the Criminal Act should be applied for the period exceeding five years when he was detained pending trial abroad. The Court rejected the Defendant's claim and also confirmed that the lower court did not err in applying the Criminal Act.

\section{Issues Presented}

One of the main issues, in this case, was how to interpret "an offender who has undergone the whole or partial execution of sentence imposed abroad" under Article 7 of the Criminal Act. ${ }^{2}$ The Court reviewed whether a person accused in a criminal case and detained pending trial for a considerable period before being acquitted in a foreign country falls under this provision and whether such period detained before trial can be deemed sentence executed abroad as prescribed by Article 7 of the Criminal Act.

\section{Judgment}

Criminal sentencing is exercised by the penal authority as a part of state sovereignty. Therefore, even if punishment imposed on an offender by a foreign court is final and conclusive, Korean courts are not bound by such foreign judgment, and the doctrine of double jeopardy cannot be applied since it does not have any res judicata in Korea. The Court found that the legislative intent of Article 7 was to mitigate possible disadvantages experienced by a criminal defendant facing punishment for the same offense under Korean penal law. Yet, in view of the language and purpose of Article 7 , "an offender who has undergone the whole or partial execution of sentence imposed abroad" should be construed as an offender who has actually undergone the whole or partial execution of sentence, such as imprisonment or fine, imposed upon conviction by a foreign court. Therefore, the Court confirmed that, even if having been detained pending trial for a considerable period prior to acquittal in that country, a person accused in a criminal case but then acquitted abroad cannot be

2 Hyeongbeob [Criminal Act], Act No. 14415, Dec. 20, 2016, art. 7 (S. Kor.).

Article 7 (Inclusion of Sentence Executed Abroad)

If an offender has undergone the whole or partial execution of sentence imposed abroad because of crime, the sentence either wholly or partially executed shall be included in the sentence to be declared in Korea.

(This Article is amended by Act No. 14415, December 20, 2016 in accordance with the Constitutional Court's decision [2013Hun-Ba129,] May 28, 2015 that held this paragraph unconstitutional and inconsistent with the Constitution.) 
regarded as falling under "an offender who has undergone the whole or partial execution of sentence imposed abroad" and the period detained before trial abroad cannot be deemed sentence executed abroad as prescribed by Article 7 of the Criminal Act.

\section{Comment}

In this case, it is interesting to read dissenting opinions by five Justices from the perspective of human rights. They admitted that Article 7 of the Criminal Act could be construed as inapplicable to a person who was merely held in pretrial detention before acquittal abroad rather than an offender who has undergone the whole or partial execution of sentence imposed upon conviction by a foreign court. However, five dissenting judges maintained that the number of days detained pending trial should be either wholly or partially counted toward the sentence to be declared in Korea based on analogical interpretation. This is because if a criminal defendant, who was held in pre-trial detention before being acquitted abroad, were to have been prosecuted for the same offense in Korea and subsequently punished under Korean criminal law without taking into consideration the fact that the defendant had been previously detained abroad, then this could be deemed an excessive infringement of the defendant's right to personal liberty. This corresponds with the constitutional spirit declaring the principle of due process to protect personal liberty, too. Furthermore, to fully realize the legislative intent of Article 7 of the Criminal Act, for example for the protection of human rights to mitigate any disadvantages that a criminal defendant may experience due to double punishment at home and abroad, it would be more tenable to allow the analogical application of Article 7 of the Criminal Act rather than relying on a judge's sentencing decision that regards pre-trial detention abroad as a factor in the sentencing guidelines.

\section{CUSTOMARY INTERNATIONAL LAW - TREATIES - JURISDICTION}

Decision of Constitutional Court Concerning the 'Impeachment of the President', Constitutional Court Decision 2016Hun-Na1

(decided on March 10, 2017)

\section{Issues Presented \& Judgment}

This case did not directly deal with the implementation of international law, but in the decision, the Court confirmed the legal status of international 
treaties and customary international law under a domestic legal system in Korea as below.

The Constitution provides that the ground for impeachment is the "violation of the Constitution or other laws," and by giving the Constitutional Court jurisdiction over adjudication on impeachment, prescribes that the impeachment procedure is normative, and not political. The purpose of the impeachment system is to realize the principle of the rule of law which prescribes that nobody is above the law, and to protect the Constitution. The considerable political chaos that may occur by removing a President elected by the public from office should be deemed an inevitable cost of democracy paid by the nation in order to protect the basic order of liberal democracy.

Article 65 of the Constitution provides that the ground for impeachment is a 'violation of the Constitution or other laws in the performance of official duties' committed by the President. The "official duties" as provided here mean the duties that are inherent in particular governmental offices as provided by law and other duties related thereto as commonly understood, and thus is a concept that includes not only acts based on law, but also all of those performed by the President in his or her office with respect to the implementation of state affairs. The "Constitution" includes the unwritten constitution formed and established by the precedents of the Constitutional Court as well as the express constitutional provisions. "Other laws" include not only statutes in their formal context, but also, inter alia, international treaties that have the same force as statutes and international law that has been generally accepted (2004Hun-Na1, May 14, 2004).

Municipal LAW - TAX - Treaties

Decision of Supreme Court Concerning the Revocation of Disposition Imposing Corporate Tax, Supreme Court Decision 2015Du2611

(decided on December 15, 2016)

\section{Facts of the Case \& Issues Presented}

Lone Star Fund, a private equity fund, which was launched in 1995, made over 700 investments worldwide approximately KRW $5^{\circ}$ trillion in total. While 
investing in Korea since 1999, Lone Star Fund established Lone Star Fund III in July 2000. A limited partnership established under the laws of the state of Delaware, U.S.A., Lone Star Fund III consists of Plaintiff Lone Star Fund III (U.S.) LP, Plaintiff Lone Star Fund III (Bermuda) LP, and Hudco Partners Korea Ltd., a corporation established under the laws of Bermuda for the purpose of offering investment opportunities to Lone Star Fund's officers, executives, and employees worldwide. By reviewing the various tax benefits under the tax and corporate laws of each country and tax treaties to which Korea is a party, Lone Star Fund III sought means to avoid capital gains tax, etc. in the event it invested in real property in Korea. Specifically, it sought to design an optimal investment structure using special purpose companies overseas. Within this context, Lone Star Fund III bought Gangnam Finance Center in 2001 via its company Star Holdings in Belgium, and then sold it in 2004, making some 245 billion won in profit. The Plaintiff, however, did not pay tax on the sale. In 2005, the National Tax Service's Yeoksam branch ordered Lone Star Fund III to pay some 100 billion won in tax on the profit it made selling the building in Gangnam. It objected, saying it shouldn't be subject to income tax as a foreign company. The case made it to the Supreme Court, which in 2012 judged in favor of the Lone Star Fund III, ruling that while it is subject to corporate tax, it is not subject to income tax. The Yeoksam tax office then imposed a corporate tax of 104 billion won on Lone Star, which said it was not liable due to a tax treaty between Belgium and Korea, as it bought and sold the building via its company in Belgium.

\section{Judgment}

The court's major rulings can be summarized as follows:

The principle of substantial taxation as provided under Article 14(1) of the former Framework Act on National Taxes (amended by Act No. 8830, Dec. 31, 2007 ... ) means that, in the event there is another person to whom such taxable items as income, profit, property, or transaction substantially accrue, apart from the one nominally designated, tax authority shall deem liable for tax the one to whom such items substantially accrue, instead of the nominally designated person in formality or appearance.... $[t]$ he determination whether the organization may be deemed a foreign corporation shall depend on whether the organization may be deemed an independent agent to which rights and obligations accrue, apart from its constituent members, under the private law of the Republic of Korea in light of the statutory content of the country where the organization was established and the substance of the organization, 
barring any special provision under the former Corporate Tax Act as to the specific requirements for a foreign corporation other than the location of the headquarters or principal office.... [A]rticle 27 of the Convention Between the Republic of Korea and the United States of America for the Avoidance of Double Taxation and the Prevention of Fiscal Evasion with Respect to Taxes on Income and the Encouragement of International Trade and Investment . . . provides not only for mutual agreement on specific tax disposition, but also for mutual agreement in the general sense aimed at resolving "difficulties or inquiries arising in connection with the application of the Convention." ... [I]t is evident that income derived from a transfer of stock of a corporation in excessive possession of real property ... apparently constitutes capital gains from that transfer of stock. ... [A]ccordingly, Korea may tax the capital gains from the transfer of stock of a corporation in excessive possession of real property situated in Korea. In such a case, the mere fact that the agreement has not undergone domestic procedures tantamount to treaty amendment does not constitute a ground for denying its validity.

\section{Comment}

The lower court ruled in favor of the tax office, saying the bilateral tax treaty contains agreements on preventing tax evasion and "Star Holdings appears to be a company built solely for the purpose of avoiding paying taxes and the regulation that waives taxes on foreign companies therefore cannot be applied to it." The higher court doled out a similar judgement, but maintained that 39.2 billion won imposed on Lone Star as additional tax should be cancelled because the Yeoksam tax office did not provide an explanation on why and how it was calculated. Then, this Supreme Court finally ruled that the company should pay 64.8 billion won in corporate tax. Overall, all appeals were dismissed by the Supreme Court.

\section{LAW OF THE Sea - Legislation ANd Administrative REgUlations}

Act on the Exclusive Economic Zone and Continental Shelf (Amended Mar. 21, 2017 by Act No. 14605)

On March 21, 2017, this Act was amended with the purpose to protect rights and interests of the Republic of Korea in the sea and contribute to establishing international maritime order by prescribing the sovereign right exercised by 
the Republic of Korea and jurisdiction thereof regarding its exclusive economic zone and continental shelf in accordance with the United Nations Convention on the Law of the Sea.

Based on Art. 2, the continental shelf of the Republic of Korea comprises the seabed and subsoil of the submarine areas that extend beyond its territorial sea throughout the natural prolongation of its land territory to the outer edge of the continental margin. Art. 3 stipulates that the Republic of Korea shall have sovereign rights to explore its continental shelf and to exploit mineral of the seabed and subsoil, other non-living resources, and sedentary species (referred to in Article 77(4) of the Convention). Also in Art. 4, it is confirmed that in the exclusive economic zone and continental shelf of the Republic of Korea, foreign states or foreigners may, on condition that they shall comply with the relevant provisions of the Convention, enjoy the freedom of navigation, overflight, the laying of submarine cables or pipelines, and other internationally recognized lawful uses of the sea in relation to the freedom. Furthermore, Art. 5 is amended for the relevant agency to take necessary measures including the exercise of the right of hot pursuit referred to in Article III of the Convention, stopping or boarding vessels, inspection, arrest, and judicial proceedings against the persons who infringe the rights referred to in Article 3 in the exclusive economic zone and continental shelf of the Republic of Korea or who are deemed to be under suspicion of violating the statutes of the Republic of Korea applied in relation to the relevant exclusive economic zone and continental shelf.

\section{ENVIRONMENTAL LAW - HAZARDoUS WASTE - LEgISLATION ANd Administrative Regulations}

\section{Act on the Transboundary Movement of Hazardous Wastes and Their Disposal (Amended Apr. 18, 2017 by Act No. 14784)}

The purpose of this Act is to prevent any environmental pollution caused by the transboundary movement of wastes and to promote international cooperation, and to contribute to environmental conservation and qualitative improvement in the lives of people by implementing the Basel Convention on the Control of Transboundary Movements of Hazardous Wastes and Their Disposal, and bilateral, multilateral, or regional agreements based on the aforesaid Convention and by restricting the export or import of wastes, and the transit of wastes across the Republic of Korea. Based on Art. 18, any person who intends to export or import wastes subject to export or import control shall make a 
declaration for export or import to the Minister of Environment along with the type, quantity, and plan of disposal of such wastes. And a person who fails to make a declaration for export or import or makes a false declaration for export or import shall be punished by imprisonment with labor for not more than two years or by a fine not exceeding 20 million won.

\title{
InTERnATIONAL ECONOMic LAW - CUSTOMS ANd DUties - LEgislation AND ADMinistrative REgulations
}

\author{
Act on Origin Labeling of Agricultural and Fishery Products (Amended \\ Oct. 13, 2017 by Act No. 14902)
}

The purpose of this Act is to protect producers and consumers by guaranteeing the right of consumers to be informed and inducing fair trade by having the producers indicate the country of origin of agricultural and fishery products or the processed products thereof, etc. in an appropriate and reasonable manner. Based on amended Art. 7, the Minister of Agriculture, Food and Rural Affairs, the Minister of Oceans and Fisheries, the Commissioner of the Korea Customs Service or the Mayor/Do Governor shall require the relevant public officials to collect or investigate agricultural and fishery products or the processed products thereof subject to labeling of the country of origin, as prescribed by Presidential Decree, in order to ascertain whether country of origin labels are placed and the labeled matters, the methods of labeling, etc. are appropriate pursuant to Article 5. In such cases the affairs for collection or investigation of the Commissioner of the Korea Customs Service are limited to agricultural and fishery products or the processed products of agricultural and fishery products (excluding the processed products which are processed in the Republic of Korea) which are imported among products subject to labeling of the country of origin under Article 5 (1). Here, the term "place of origin" means a country, area, or waters where agricultural products or fishery products are produced, gathered, or caught.

\section{Human Rights - Rights of the Child - International Agreements}

Withdrawal of a Reservation of Article 21 Paragraph (a) of the Convention on the Rights of the Child (Withdrawal of a Reservation on Aug. 11, 2017) 
To implement Article 21 paragraph (a) of the Convention, the Government revised the Act on Special Cases Concerning Adoption in August 2011, under which both domestic and intercountry adoptions are subject to court authorization. Also, a new provision on permission from the family court concerning the adoption of minors was established in the Civil Act in February 2012. In July 2013, the Government introduced in Family Litigation Act a procedure for permission for adoption, requiring the Family Court to hear the opinion from a prospective foster child where the prospective foster child is at least 13 years of age. Upon refurbishing the adoption system, the Government ratified Article 21 paragraph (a) of the Convention, which it had reserved at the time of its accession to the Convention, and finalized the procedures to withdraw the reservation in August 2017.

Article 21 stipulates that:

States Parties that recognize and/or permit the system of adoption shall ensure that the best interests of the child shall be the paramount consideration and they shall: (a) Ensure that the adoption of a child is authorized only by competent authorities who determine, in accordance with applicable law and procedures and on the basis of all pertinent and reliable information, that the adoption is permissible in view of the child's status concerning parents, relatives and legal guardians and that, if required, the persons concerned have given their informed consent to the adoption on the basis of such counselling as may be necessary. 